\title{
Mepolizumab - therapeutic strategy for a paediatric patient with eosinophilic granulomatosis with polyangiitis
}

\author{
Lota Ozola ${ }^{1}$, Elīna Aleksejeva ${ }^{1}$, Diāna Stoldere ${ }^{1}$, Ineta Grantiņa ${ }^{1}$, Zane Dāvidsone ${ }^{1}$, Ruta \\ $\breve{S}$ antere ${ }^{1}$, Ieva Cirule ${ }^{1}$, and Alvils Krams ${ }^{2}$ \\ ${ }^{1}$ Bērnu klīniskā universitātes slimn̄̄ca \\ ${ }^{2}$ Rìgas Austrumu klīniskā universitātes slimnīca
}

January 12, 2022

\begin{abstract}
Eosinophilic granulomatosis with polyangiitis (EGPA; formerly known as Churg-Strauss syndrome) is classified as an antineutrophil cytoplasmic antibody (ANCA)-associated small vessel vasculitis. It is a multisystem disorder and can affect every organ system. EGPA is a rare disease, with an estimated prevalence of 1/70,000-100,000 in Europe. As its onset usually occurs in adulthood, data from paediatric patients are limited. We present here a very rare practical EGPA clinical case involving a paediatric patient. Presently, data on mepolizumab usage in paediatric patients are limited, with only a few case reports published.
\end{abstract}

\section{Hosted file}

Case report. ERJ.labots_CSE_Edited_CA. DS. 11.01.docx available at https://authorea.com/ users/455230/articles/552589-mepolizumab-therapeutic-strategy-for-a-paediatric-patientwith-eosinophilic-granulomatosis-with-polyangiitis

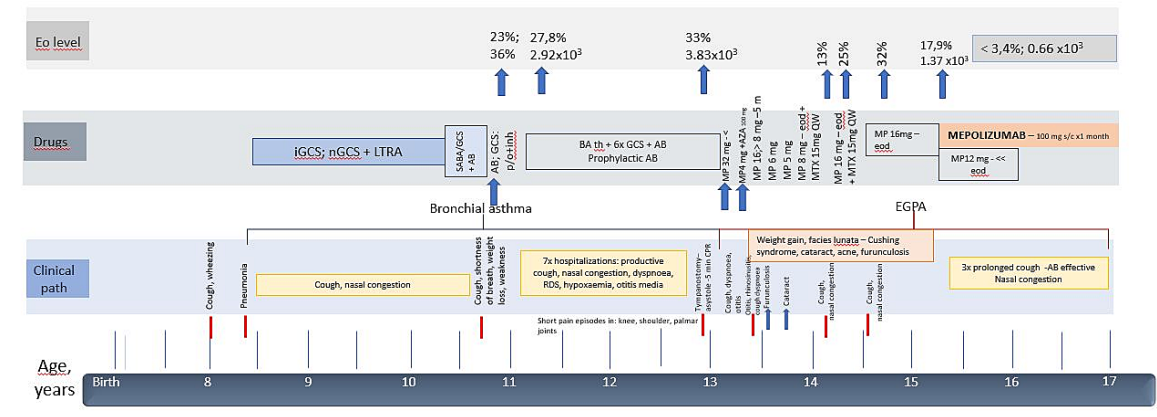

